Journal of Social and Development Sciences

Vol. 2, No. 2, pp. 58-65, Aug 2011 (ISSN 2221-1152)

\title{
A Study Examining the Effects of Oil Export in Iran
}

\author{
${ }^{1}$ Safdari Mehdi, ${ }^{2}$ Motiee Reza \\ ${ }_{1}^{1}$ University of Qom, Iran \\ 2Department of Economics, Babol Branch, Islamic Azad University, Babol, Iran \\ *rm.search2011@gmail.com
}

\begin{abstract}
The effect of increasing oil incomes on oil exporter countries is the main issues of political economy. Generally and especially about Iran can be recognized this effect in the government spending method, economic structure and behavior of government within the country. Since oil incomes aren't result of the performance of economic activities, consequently increasing does not show the real economic prosperity. The purpose of this study is to determine the relationship between oil exports and economic growth in Iran. The data were collected from 1961-2006 and were analyzed using Cointegration, Error Correction Model, and VEC Granger causality/Wald Exogeniety model. The result of the analyses showed that there was significant relationship between oil incomes and economic growth. It showed that increasing in oil price rate lead to increasing in the government costs consequently it affect on the exchange rate and lead to increasing in real exchange rate. Therefore oil incomes are regarded as an important factor in Iran's economic growth.
\end{abstract}

Keywords: Export, oil export, non-oil exports, ordinary least square (OLS), economic growth, Iran.

\section{Introduction}

Every economic system, to produce products and exported to the outside world and instead provides its own import requirements. Normally, the export items have more diverse, is less the economy vulnerable to fluctuations in world markets and more stable would have been the external dimensions. Iran's economy various reasons that is related to political, it have been product minor productions and exported to overseas and generally for providing its import needs is associated to crude oil exports. After discovering huge reserves of natural gas in 1959 in the Netherlands and increasing exchange incomes resulted of the export, this country was faced with many problems that often named to Dutch disease. After that whenever in one country be increased exchange incomes in export sector very much, the risk of this disease occurs in the minds of economists including the Iran's economy was faced to imbalance in the macroeconomic. In the first development plan (1948-1955) was predicted that external debt should be provide 31 percent of total income sources and 60 percent of total debt but this program was not implemented actually starting with the oil nationalization movement and the Mossadegh government. In Second Development Plan external debts was allocated to 27 percent of total income sources and 86 percent of total debts during the program and this topic in Third Development Plan received respectively to 14 percent and 91 percent and in the fourth development plan to 14 percent and 53 percent. The beginning of this plan oil price from 1.9 dollar received to 10 dollar and oil incomes were sent to the government treasurer and this problem was led to Dutch disease such as Iran that large part of export revenues included oil and petroleum products. Based on central bank of Iran (2008) moderately 90 percent of total export incomes and 60 percent of government incomes in the annual budget were allocated to raw export incomes. Therefore it is essential to the reviewing reception of oil price fluctuations rate and its impact on the economy.

In developing countries that they are oil exporter, oil is good export and receives to government income it and the government decision is crucial as way to spend the incomes. Also in developed countries economic fluctuations will affect on their condition due to the high volume of imports. Real exchange rate shows the national economic situation in interior and exterior scenes and the national competitiveness in global markets. After increase crude oil prices in the first oil shock, the share of foreign exchange earnings from crude oil sales in the GDP decreased strongly and this economic dependence on oil incomes led to Iran's economic dependence to receive regular and growing oil incomes. With such conditions, economic development program was involved in leaps and bounds because with unexpected fluctuations in the oil prices and consequently the revenues from exports the planners are forced to rethink or abandon many of 
the programs. On the one hand, high volume of foreign exchange earnings should be allocated to imports of intermediate and capital and consumer goods due to pathological structure of the national economy to meet the needs of society and on the other hand, foreign exchange revenues from oil sales has an important role in national's foreign exchange reserves due to the low share of non-oil exports. Oil prices fluctuations are the main economic fluctuations resources in oil producer countries such as oil prices surge after 1973 year that influenced on economic in oil producer countries. Increasing oil price can affect on prices by various methods such as by increasing goods price imported or by increasing transportation cost due to increasing fuel cost, prices of imported raw materials, technology and production machines Imported. With rising oil prices, demand increase due to increasing oil incomes and since increasing domestic product has limited in short term consequently the main part of oil incomes increased leads to excess demand by importing and On the other hand with increasing demand, domestic product Can be increase during in the few years if investment be suitable. Also editing economic- Social development plans and Setting the annual national budget is required to recognition and doing accurate predictions of the impact of oil price fluctuations on macroeconomic variables so that planners can be reduce the impact it on macro variables during occurred the oil shock and adopt the correct policies.

In Iran such as other countries, growth and achieve the high rate is one of the goals of government. Hence review factors impact on growth including exports can be the way for economic policy maker's framework intended purpose. The purpose in this study is the survey effect of oil exports on economic variables in Iran and we want to estimate model the using Ordinary Least Squares (OLS) and time-series data of 1961-2006 published by central bank of Iran and statistical center of Iran and then to test hypotheses related to research based on statistical inference and also we want to answer this question: can be oil export a cause for economic sectors growth?

Review process oil in Iran: In terms of hydrocarbons it is hard not to speak in superlatives about Iran. The country ranks among the world's leading producers and exporters of oil and gas, as it possesses the world's third largest oil reserves after Saudi Arabia and Canada, and the world's second largest natural gas reserves behind Russia. Furthermore, Iran ranks as the world's fourth largest oil exporter and is one of the founding members of the Organization of Petroleum Exporting Countries (OPEC). In 2011, Iran will take on the rotating OPEC presidency after a hiatus of 36 years. While rich in oil and gas however, Iran is looking to rapidly increase its electricity generating capacity and improve energy conservation policies. In our energy review, TBY talks to the key players in the sector and provides all the data investors need to know.

Figure 1: OPEC Total Crude Oil Production (Million barrels/day)

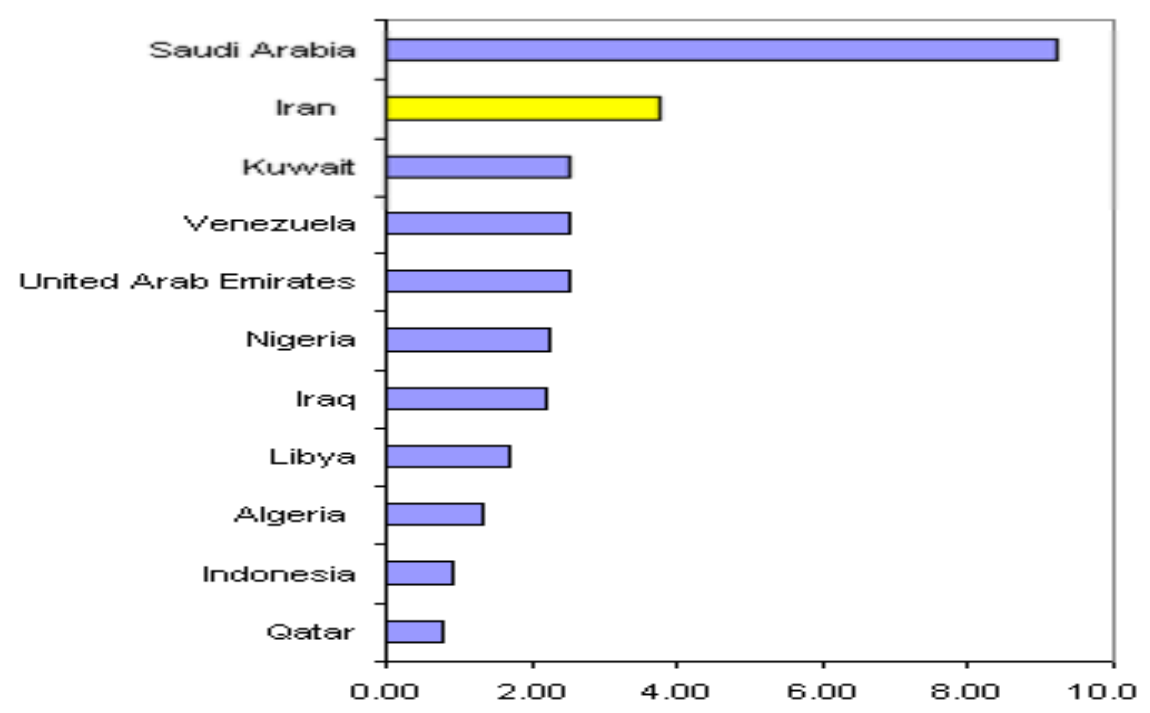

During 2005, Iran produced about 4.24 million bbl/d of total liquids. Of this, 3.94 million bbl/d is crude oil, roughly 5 percent of world crude production. Iran's current sustainable crude oil production capacity is estimated at 3.8 million bbl/d, which is around 310,000 bbl/d below Iran's latest (July 1, 2005) OPEC 
production quota of 4.110 million bbl/d. Through the first half of 2006, the EIA places Iran's crude oil production at 3.75 million bbl/d. Iran's domestic oil consumption, 1.5 million bbl/d in 2005, is increasing rapidly as the economy and population grow. Iran subsidizes the price of oil products heavily, which contributes to rising domestic consumption. Iran's existing oilfields have a natural decline rate estimated at 8 percent onshore and 10 percent per year offshore. The fields are in need of upgrading, modernization, and enhanced oil recovery (EOR) efforts such as gas reinjection. Current recovery rates are just 24-27 percent, compared to a world average of 35 percent. Iran also needs to increase its search for new oil, with only a few exploration wells being drilled in 2005. With sufficient investment, Iran could increase its crude oil production capacity significantly. The country produced 6 million bbl/d of crude oil in 1974 but has not come close to recovering to that level since the 1978/79 Iranian revolution. Still, Iran has ambitious plans to increase oil production to more than 5 million bbl/d by 2010, and 8 million bbl/d by 2015. The country will require billions of dollars in foreign investment to accomplish this. Oil export makes more country's export incomes so that based on these incomes are regulated more economic programs. In during 1968-1970, oil export has climbed fairly balanced and in 1974 oil incomes has increased immediately due to price shock so that became almost fourfold than previous year and in 1977 reached to highest level and this incremental process has continued to 1978 year. In 1980 oil incomes decreased by Iraq attacks on Iran and the occupation of oil-rich regions and in 1986 reached to the lowest. After the war, oil export has climbed but in 1998 decreased again due to economic boycott in South East Asia and rising OPEC production ceiling and after these years oil export increased to 2006 year because increasing oil price due to political problems in Venezuela and America's war in Iraq.

Table 1: Average annual export and export growth rates in economic sectors

\begin{tabular}{|c|c|c|c|c|c|c|c|c|}
\hline \multirow[t]{2}{*}{ Period } & \multicolumn{4}{|c|}{ Average annual export growth (percent) } & \multicolumn{4}{|c|}{ Average annual exports (million dollars) } \\
\hline & Oil & Services & Agriculture & $\begin{array}{c}\text { Industry } \\
\text { and } \\
\text { mining }\end{array}$ & Oil & Services & Agriculture & $\begin{array}{c}\text { Industry } \\
\text { and } \\
\text { mining }\end{array}$ \\
\hline 1961-1971 & 16.9 & 36.41 & 18.24 & 20.32 & 1535.44 & 127.19 & 131.82 & 37.23 \\
\hline $1972-1977$ & 46.5 & 63.08 & 12.52 & 15.01 & 16857.83 & 2176 & 407.1 & 407.1 \\
\hline 1978-1988 & 2.84 & -16.58 & 13.98 & 15.32 & 14741.09 & 1435.91 & 527.07 & 527.07 \\
\hline 1989-1993 & 10.6 & 24.69 & 29.57 & 52.08 & 15451 & 930.4 & 1676.38 & 1676.38 \\
\hline 1994-1999 & 9.51 & 23.81 & -12.29 & 6.47 & 15373.4 & 1466.8 & 1537.76 & 1537.76 \\
\hline $2000-2004$ & 18.5 & 39.28 & 5.52 & 19.67 & 26050.91 & 4735.7 & 1750.95 & 1750.95 \\
\hline $2005-2006$ & 31.7 & 11.30 & 26.43 & 42.97 & 57915.5 & 8138.81 & 2778.48 & 2778.48 \\
\hline
\end{tabular}

Source: Central Bank of Iran

Table 2: The average combined share of exports in economic sectors (percent)

\begin{tabular}{|c|c|c|c|c|}
\hline Period time & Oil & Agriculture & Industry and mining & Services \\
\hline 1961-1971 & 84 & 7 & 2 & 7 \\
\hline $1972-1977$ & 85 & 3 & 1 & 11 \\
\hline 1978-1988 & 88 & 4 & 1 & 7 \\
\hline 1989-1993 & 83 & 9 & 3 & 5 \\
\hline 1994-1999 & 76 & 9 & 8 & 7 \\
\hline $2000-2004$ & 73 & 5 & 9 & 13 \\
\hline $2005-2006$ & 74 & 4 & 11 & 10 \\
\hline
\end{tabular}

Source: Central Bank of Iran

\section{The Previous Studies}

Kamps and Pierdzioch (2002) have studied monetary policy rules and oil price shocks. Their analysis shows that it is important to distinguish between alternative price indices (CPI, core CPI, and GDP deflator) when modeling the effects of oil price increases. Their results demonstrate that targeting the change in the GDP deflator is an inferior monetary policy strategy in the presence of oil price shocks. Lee and Ni (2002) have examined he dynamic effects of oil price shocks: using industry level data. This paper analyzes the effects of oil price shocks on demand and supply in various industries whit VAR models. The result show for many 
other industries, with the automobile industry being a particularly important example, oil price shocks mainly reduce demand. The paper suggests that oil price shocks influence economic activities beyond that explained by direct input cost effects, possibly by delaying purchasing decisions of durable goods. Study of Cunado \& Gracia (2004) investigated oil prices economic activity and inflation: evidence for some Asian countries, they studied for six Asian countries over the period 1975Q1-2002Q2. The results suggested that oil prices had a significant effect on both economic activity and price indexes, although the impact was limited to the short run and more significant when oil price shocks are defined in local currencies and found evidence of asymmetries in the oil prices-macro economy relationship for some of the Asian countries. Study of JiménezRodríguez \& Sanchez (2004), has entitled oil Price Shocks and Real GDP Growth: Empirical Evidence for Some OECD Countries, This paper estimated Multivariate VAR analysis is carried out using both linear and nonlinear models. They found evidence of a non-linear impact of oil prices on real GDP. Among oil importing countries, oil price increases are found to have a negative impact on economic activity in all cases but Japan. Moreover, the effect of oil shocks on GDP growth differs between the two oil exporting countries in their sample, with oil price increases affecting the UK negatively and Norway positively.

Berument and Ceylan (2004) examined how oil price shocks affect the output growth of selected Middle East and North African countries that are either exporters or net importers of oil commodities. In this respect, they used a structural vector auto regressive (SVAR) model, focusing explicitly on world oil prices and the real GDP over the period of 1960-2003. Their impulse response analysis suggests that the effects of the world oil price on GDP of Algeria, Iran, Iraq, Jordan, Kuwait, Oman, Qatar, Syria, Tunisia and UAE are positive and statistically significant. However, for Bahrain, Egypt, Lebanon, Morocco and Yemen they did not find a significant impact on oil price shocks. Study of Mehr and Niki (2006) has entitled oil impacts and its dynamic effects for variable macroeconomic. The SVAR model was used in this article and for to introduce structural impacts of Blanchard was used long run limitation approach. The result of this estimate for Iran was compared with three oil exporting countries (Indonesia, Kuwait and Saudi Arabia, Countries with same economics conditions) in 1960-2003. Analyzing data was done by FEVDs and IRFs. . The results show that, external degree of oil price in both Kuwait and Saudi Arabia is less than Iran and Indonesia. moreover, the impact on oil price have been the main reason of change in GDP and imports in Iran and Saudi Arabia, as the impact on imports is the main reason in the Indonesia and Kuwait. The impact of oil price is the positive factor on imports, GDP, and price indicators in any countries. Olomola and Adejumo (2006) examined the effects of oil price shocks on output, inflation, real exchange rate and money supply in Nigeria using quarterly data from 1970 to 2003. Using VAR methodology they find that oil price shocks do not have any substantial effect on output and inflation. Oil price shocks only significantly determine the real exchange rate and in the long run money supply. Olomola and Adejumo conclude that this may squeeze the tradable sector, giving rise to the "DutchDisease". Farzanegan \& Markwardt (2007) studied the effects of oil price shocks on the Iranian Economy. Due to the high dependence on oil revenues, oil price fluctuations have a special impact on the Iranian economy. By applying a VAR approach, this paper analyzes the dynamic relationship between asymmetric oil price shocks and major macroeconomic variables in Iran. Contrary to previous empirical findings for oil net importing developed countries, oil price increases (decreases) have a significant positive (negative) impact on industrial output. Unexpectedly, we cannot identify a significant impact of oil price fluctuation on real government expenditures. The response of real imports and the real effective exchange rate to asymmetric oil price shocks are significant. Furthermore, the response of inflation to any kind of oil price shocks is significant and positive.

\section{Methodology}

Data for exports, imports and GDP are annual and obtained from the Central Bank of Iran and the Islamic Republic of Iran Customs Administrations. Variables are in natural log and in constant dollar. They are:

YN= Real per capita export GDP. Export GDP is measured as Gross Domestic Product minus Non exports. Exports are subtracted GDP for avoiding exports biasness and the spurious correlation between exports and growth. EX is Exports of oil and non oil and IM is total imports. It is incorporated for avoiding a missing variable. It an important channel for affecting the growth of GDP through the imports of capital and intermediate goods. With these variables, the paper estimates the following simple model:

$Y N=f(E X, I M)$ 
This paper uses Vector Error Correction estimates and VEC Granger Causality/ Block Exogeneity Wald Tests for finding causal relation and the direction of causality. Where $\mathrm{T}$ denotes the time trend and the failure to reject the null hypothesis of unit root $(\rho=1)$ signifies the existence of a non-stationary process. The result of the ADF test is provided in Table 3. Second, the cointegration properties of the variables are examined using Johansen (1991 and 1995a) VAR based co-integration test. Results of Co-integration test is provided in Table 4. Third, having established that a co-integrating relationship is present among variables in level form, Vector Error Correction model which combines both short term properties of economic relationship in first difference form as well as the long term relationship in level form is estimated from the following:

$\Delta \mathrm{YNt}=\sum \alpha_{1 \mathrm{i}} \Delta \mathrm{YN}_{\mathrm{t}-\mathrm{i}}+\sum \beta_{1 \mathrm{i}} \Delta$ Oil EX $\mathrm{t}_{\mathrm{t}-\mathrm{i}}+\sum \varphi_{1 \mathrm{i}} \Delta$ Non Oil EX $\mathrm{EX}_{\mathrm{t}-\mathrm{i}}+\sum \Psi_{1 \mathrm{i}} \Delta \mathrm{IM}_{\mathrm{t}-\mathrm{i}}+\lambda \mathrm{ECT}_{\mathrm{t}-\mathrm{i}}+\varepsilon_{\mathrm{t}}$ $\Delta$ Oil Ex $\mathrm{t}_{\mathrm{t}}=\sum \beta_{2 \mathrm{i}} \Delta$ Oil EX $\mathrm{t}_{\mathrm{t}-\mathrm{i}}+\sum \alpha_{2 \mathrm{i}} \Delta \mathrm{YN}_{\mathrm{t}-\mathrm{i}}+\sum \varphi_{2 \mathrm{i}} \Delta$ Non Oil EX $\mathrm{EX}_{\mathrm{t}-\mathrm{i}}+\sum \Psi_{2 \mathrm{i}} \Delta \mathrm{IM}_{\mathrm{t}-\mathrm{i}}+\lambda \mathrm{ECT}_{\mathrm{t}-\mathrm{i}}+\varepsilon_{\mathrm{t}}$ $\Delta$ Non Oil $\mathrm{Ex}_{\mathrm{t}}=\sum \varphi_{3 \mathrm{i}} \Delta$ Non Oil EX $\mathrm{E}_{\mathrm{t}-\mathrm{i}}+\sum \beta_{3 \mathrm{i}} \Delta$ Oil EX $\mathrm{Et}_{\mathrm{t}}+\sum \alpha_{3 \mathrm{i}} \Delta \mathrm{YN}_{\mathrm{t}-\mathrm{i}}+\sum \Psi_{3 \mathrm{i}} \Delta \mathrm{IM}_{\mathrm{t}-\mathrm{i}}+\lambda \mathrm{ECT}_{\mathrm{t}-\mathrm{i}}+\varepsilon_{\mathrm{t}}$ $\Delta \mathrm{IM}_{\mathrm{t}}=\sum \Psi_{4 \mathrm{i}} \Delta \mathrm{IM}_{\mathrm{t}-\mathrm{i}}+\sum \varphi_{4 \mathrm{i}} \Delta$ Non Oil EX $\mathrm{E}_{\mathrm{t}-\mathrm{i}}+\sum \beta_{4 \mathrm{i}} \Delta$ Oil EX $\mathrm{E}_{\mathrm{t}-\mathrm{i}}+\sum \alpha_{4 \mathrm{i}} \Delta \mathrm{YN}_{\mathrm{t}-\mathrm{i}}+\lambda \mathrm{ECT}_{\mathrm{t}-\mathrm{i}}+\varepsilon_{\mathrm{t}}$

Where Y, Oil EX, Non Oil Ex and IM are stationary processes, ECT represents one period lagged error correction term captured from the co-integrated regression from (3, 4, and 5). $\alpha, \beta, \psi, \varphi$ and $\lambda$ are coefficient, and $\varepsilon$ is error term. The null hypothesis that EX does not Granger cause $\mathrm{Y}$ is rejected not only if $\Sigma \beta, \Sigma \psi, \Sigma \varphi$ are jointly significant but also if the coefficient of ECTt-1 is significant (Miller and Russek, 2001). But in the Error Correction Model, the causality inference is obtained through the significance of $\lambda$. That is, the null hypothesis that EX does not Granger cause $Y$ is rejected if $\lambda$ is statistically significant even if $\Sigma \beta i$ and $\Sigma \psi$ are not jointly significant. The direction of causality is also tested though the VEC Granger Causality/Wald Block Exogeneity tests. The results of error correction estimates and VEC Granger causality test are provided in Table 5.

Unit root test by Augmented Dickey - Fuller (ADF) and Phillips Perron (PP): Table C.1 reports the ADF tests and the Philips-Perron Tests for the stationary of each variable, over sample period 1988: I to 2004: IV. We applied models with and without trend. For the log-level series, the ADF test (Dickey and Fuller (1979)) does not reject the null hypothesis of a unit root at 95 percent confidence level. However, the Phillips-Perron tests (Phillips and Perron, (1988) reject the null hypothesis of a unit root (non stationary) at the 99 percent confidence level. After first differencing, each series rejects the null hypothesis of non stationary at the 99 or 95 percent levels. Relying on ADF tests, all variables have unit root in levels and are stationary after first differencing. Since all the series are non stationary at the levels and integrated of the same order, this suggests a possibility of the presence of cointegrating relationship between oil prices and the Iranian economic variables. One of the methods for determining stationary is Unit root test by Augmented Dickey Fuller (ADF), this test is based on following equation:

$$
\Delta Y_{t}=\alpha+\beta t+m Y_{t-1}+\sum_{i=1}^{m} \alpha_{i} \Delta Y_{t-i}+\varepsilon_{t}
$$

Where $\Delta$ is operator difference first order and $\varepsilon_{\mathrm{t}}$ error pure impaired. Zero hypotheses are that time series variable has unit root. In fact, this test is the assumption having unit root (non stationary) or having no unit root (stationary).

Table 3: Result of unit root tests by Augmented Dickey-fuller (ADF) and Phillips Perron

\begin{tabular}{|c|c|c|c|c|c|c|c|c|}
\hline \multirow{3}{*}{ Variables } & \multicolumn{4}{|c|}{ ADF } & \multicolumn{4}{|c|}{$\mathbf{P P}$} \\
\hline & \multicolumn{2}{|c|}{ Without trend } & \multicolumn{2}{|c|}{ With trend } & \multicolumn{2}{|c|}{ Without trend } & \multicolumn{2}{|c|}{ With trend } \\
\hline & level & First diff. & level & First diff. & level & First diff. & level & First diff \\
\hline GDP & -1.32 & -5.54 & -2.87 & -4.65 & -1.87 & -3.98 & -1.26 & -6.29 \\
\hline OIL EX & -2.65 & -4.32 & -1.45 & -4.97 & -2.18 & -4.23 & -1.87 & -9.65 \\
\hline Non Oil EX & -2.71 & -6.46 & -1.59 & -5.91 & -1.78 & -7.54 & -1.65 & -10.32 \\
\hline IM & -1.35 & -9.24 & -2.05 & -6.12 & -2.93 & -5.56 & -2.08 & -5.88 \\
\hline
\end{tabular}

Notes: Sample is 1961: I-2006: IV for the variables in levels, and starts one quarter later for variables in first differences. We use the Schwarz Info Criterion for lag length selection. The maximal allowed number of lags was 10. Oil EX is the real oil exports for Iran; Non oil EX is the real Non oil exports for Iran. 
Heteroskedasticity and Serial Correlation: One of fundamental acceptability for regression is equality of variance sentences impaired. If variance disturbing sentences not be fixed in different observations, we will be faced to heteroskedasticity problem. Consequences due to heteroskedasticity variance disturbing sentences is that Ordinary Least Square (OLS) estimators are not efficient and estimated variances coefficient slant and also doing heteroskedasticity test and making confidence interval is rejected from the degree of credibility therefore heteroskedasticity test is necessary. Other fundamental acceptability for regression is being non-correlation disturbing sentences in different observations. If fundamental to be violated, we will face to serial correlation problem. Therefore Serial correlation test is necessary.

\section{Results}

The significance of the Error Correction Term and F-statistics, in Table 4, indicates causal and long term relation among the variables in Iran.

Table 4: Result for Error Correction Models

\begin{tabular}{lllllc}
\multicolumn{1}{c}{$\begin{array}{c}\text { Dependent } \\
\text { Variable }\end{array}$} & $\begin{array}{l}\text { t-statistics } \\
\text { for ECTt-1 }\end{array}$ & $\begin{array}{l}\text { F-statistics } \\
\text { for } \boldsymbol{\Sigma} \boldsymbol{\Delta} \text { YNt-i }\end{array}$ & $\begin{array}{c}\text { F-statistics } \\
\text { for } \boldsymbol{\Sigma} \boldsymbol{\Delta} \text { OilEXt-i }\end{array}$ & $\begin{array}{c}\text { F-statistics for } \\
\mathbf{\Sigma} \boldsymbol{\Delta} \text { Non Oil EXt-i }\end{array}$ & $\begin{array}{c}\text { F-statistics for } \\
\boldsymbol{\Sigma} \boldsymbol{\Delta} \text { IMt-i }\end{array}$ \\
\hline Oil Ex & -1.56 & $3.98^{*}$ & 1.54 & 2.54 & 2.58 \\
Non Oil EX & -1.44 & 3.98 & 1.54 & 2.54 & 2.58 \\
Yn & -0.87 & $3.98^{*}$ & 1.54 & 2.54 & 2.58 \\
IM & -1.49 & $3.98^{*}$ & 1.54 & 2.54 & 2.58 \\
\hline
\end{tabular}

*significant at a level of 1 percent

Table 5: VEC Granger Causality/Block Exogeneity Wald Test (1961-2006), Dependent Variable: D (LNGDP)

\begin{tabular}{llll}
\hline Excluded & Chi-sq & df & prob \\
\hline D(LNIM) & 0.064523 & 2 & 0.5432 \\
D(LNOILEX) & 8.213521 & 2 & 0.0155 \\
D(LN Non Oil EX) & 9.245252 & 2 & 0.0004 \\
All & 10.21543 & 4 & 0.0124 \\
\hline
\end{tabular}

Table 6: VEC Granger Causality/Block Exogeneity Wald Test (1961-2006), dependent variable: D(LNIM)

\begin{tabular}{llll}
\hline Excluded & Chi-sq & df & prob \\
\hline D(LNGDP) & 7.242523 & 2 & 0.0032 \\
D(LNOILEX) & 9.312521 & 2 & 0.0125 \\
D(LN Non Oil EX) & 11.45833 & 2 & 0.0004 \\
All & 19.54543 & 4 & 0.0204 \\
\hline
\end{tabular}

Table 7: VEC Granger Causality/Block Exogeneity Wald Test (1961-2006), dependent variable: D(LN Non OIL EX)

\begin{tabular}{llll}
\hline Excluded & Chi-sq & df & prob \\
\hline D(LNIM) & 0.714523 & 2 & 0.0002 \\
D(LNGDP) & 0.073521 & 2 & 0.0057 \\
D(LNOILEX) & 0.456872 & 2 & 0.0006 \\
All & 0.652543 & 4 & 0.0154 \\
\hline
\end{tabular}

Table 8: VEC Granger Causality/Block Exogeneity Wald Test (1961-2006), dependent variable: D (LNOILEX)

\begin{tabular}{llll}
\hline Excluded & Chi-sq & df & prob \\
\hline D(LNIM) & 0.714523 & 2 & 0.0002 \\
D(LNGDP) & 0.073521 & 2 & 0.0057 \\
All & 0.652543 & 4 & 0.0154 \\
\hline
\end{tabular}

Discussion: At first, the results shown that more than half of non-stationary variables with considering structural breaks become stationary. We found that the most significant structural breaks occurring over the last four decades and which were detected endogenously in fact coincide with the drought (1999) and oil 
price fluctuations (1976). This provides complementary evidence to models employing exogenously imposed structural breaks in the Iranian macroeconomic. VEC Granger Causality/ Block Exogeneity Wald test, in Table 4, shows Granger causality between economic growth, oil exports, non oil exports and imports. Chi-sq value associated with GDP (YN) and non oil Export (LN Non Oil EX) suggests that both GDP and non oil export Granger causes import growth and non oil exports Granger causes GDP growth. Thus, the causality runs from non oil exports to economic growth and economic growth to imports. Development of Iran non oil export is a key factor for both the domestic economic growth of Iran and the growth of imports. Iran non oil exports and non oil export generating sectors provides vital inputs for the growth of Iran's GDP and imports. The error correction term shows a long term relationship between model variables and also Based on $\mathrm{F}$ and $\mathrm{t}$ statistic, in the whole regression and all coefficients are significant and based on Durbin Watson (D.W) statistic, there is no serial correlation problem between error sentences.

\section{Conclusion and Recommendations}

Considering the above said matters, it may be concluded that increase in oil price for an exporting country like Iran would not result in appropriate outcomes. And as was mentioned earlier, it would bring up huge fluctuations to the economy to get rid of these fluctuations which are mostly due to global oil price fluctuations, the policy making shall be based upon the separation of economics from oil revenues. As well as moving towards the alternate energy resources for domestic industries and agriculture section. Therefore increase in explanatory power models with login export variable states that increasing export lead to improvement in condition of economic sectors because export development leads to attract the part of the exchange incomes result of exports to relevant sections provides economic growth areas. So is recommended applying policies that will be provided growth areas economic sectors, for this purpose a few policies of encouraging exports has included: policy of export subsidies, policy of support for agricultural inputs, reduce taxes on exports, reduce customs tariff, bond cut for outsourcing in goods export, exchange rate adjustment by the rate reductions, using of bank credit and establishment export guarantee funds. Survey the effect each of the mentioned factors on export growth depends on doing research separately. General suggested in this study is that strategy of economic sectors should be based on exporting products policy. It has also been presented in this article that regarding oil price shock over foreign exchange rate we may claim that at the beginning there would be a descending reaction while in long run it turns ascending in other words, first a negative trend and then a positive one.

So, the government is suggested to plan and perform some polices and means of proper executive in order to decrease the negative effect of oil price changes on production and improvement of agricultural sector, which will be resulted oil revenues in social economic activities development by proper management. It is very important to pay a great deal of attention to the significance of the issue in view of the dependency of Iran on oil revenues. Furthermore, since there are other factors beside oil effecting production of agricultural sector, these factors should be identified in the future research.

\section{References}

Berument, H. \& Ceylan, N. B. (2004). The Impact of Oil Price Shocks on the Economic Growth of the Selected MENA Countries, Working Paper, Bilkent University.

Blanchard, O. J. \& Watson, M. W. (1984). Are Business Cycles All Alike? National Bureauof Economic Research. Working Paper No. 1392.

Central bank of Iran: www.cbi.ir

Cunado, J. \& Gracia, F. (2004). Oil prices, economic activity and inflation: evidence for some Asian countries. Journal of Monetary Economics, 51(4), 781-808.

Dickey, D. A. and Fuller, W. A. (1979). Distribution of the Estimators for Autore-gressive Time Series with an Unit Root, Journal of the American Statistical As-sociation, 74, 427-431.

Farzanegan, M. R. \& Markwardt, G. (2007). The Effects of Oil price Shocks on the Iranian Economy", Faculty of Business, Dresden University of Technology, D-01062, Dreden, Germany.

Harris, R. I. D. (1995). Using Cointegration Analysis in Econometric Modeling, NewYork, Prentice-Hall.

Jiménez-Rodríguez, R. \& Sanchez, M. (2004). Oil Price Shocks and Real GDP Growth: Empirical Evidence for Some OECD Countries. www.ssrn.com. 
Johansen, S. (1991). Estimation and Hypothesis Testing of Cointegration Vectors in Gaussian Vector Autoregressive Models, Econometrica, 59, 1551-1580.

Johansen, S. (1995). Likelihood-based Inference in Cointegrated Vector Autoregres-sive Models, Oxford, Oxford University Press.

Kamps, C. \& Pierdzioch, C. (2002). Monetary Policy Rules and Oil Price Shocks. www.ssrn.com.

Lee K. \& Ni, S. (2002). On the dynamic effects of oil price shocks: a study using industry level data. Journal of Monetary Economics, 49(4), 823-852.

Mehrara, M. \& Niki, K. O. (2006). Oil impacts and its dynamic effects for variable macroeconomic. www.sid.ir.

Phillips, P. C. B. \& Perron, P. (1988). Testing for a unit root in time series regression, Biometrika, 75(2), 335346. 